\title{
Socio-psychological Effects of Deviation: A Sociological Appraisal
}

Mohammad Taghi Sheykhi

\author{
"Correspondence author \\ Mohammad Taghi Sheykhi \\ Professor Emeritus of Sociology \\ Alzahra University \\ Tehran \\ Iran \\ Tel: 009821-22859416 \\ E-mail:mtshykhi@alzahra.ac.ir \\ mtshykhi@yahoo.com \\ Submitted : 16 Feb 2020 ; Published : 2 Mar 2020
}

\begin{abstract}
The paper explores how people think and behave. However, various schools of thought have evolved through the development of social psychology on human behavior. While such scientists attribute a certain behavior to biological factors such as genetics, others consider early childhood experiences to be more likely affecting behavior. Such approaches or perspectives largely need investigations with special reference to the current global world. Concepts such as social influence, attribution, prejudice and discrimination, attitudes etc. play role here. The paper investigates why deviance occurs? How does it affect a society? However, since the early days of society, scholars have developed theories to explore what deviance and crime mean to society. Deviance being an accidental result of disorder and anomie, and a symptom of internal breakdown, it usually leads to crime. Method of research used in the present research is of qualitative type which is very popular in social sciences. Conclusion reaches the result that due to the unbridled and increasing urbanization and the emergence of a controversial society, deviation of socio-psychological norms is inevitable.
\end{abstract}

Keywords: Social Problems, Addiction, Social Chesion, Social Pathology, Changing Societies

\section{Introduction}

Society is a web of social relationships. In an organized society these relationships retain organized, and in a disorganized society these social relationships exhibit a lack of organization. Two problems of addiction and drug abuse generate such a disorganization in social relationships. Social disorganization is inclusive of habits, institutions, associations etc. In every society each individual has a definite status to which some roles attach. When each individual satisfactorily performs the roles which attach to his/her particular status in society, the society retains its organized cohesion. A society becomes disorganized when these roles become disorderly due to addiction, drug abuse etc. In this way, in a state of social disorganization, people forget their duties, the control of social laws diminishes, and the balance between the various parts of society is disturbed, social ideals become degenerate and the entire social structure progress towards a chaotic state.

Any deviation from the permissible acts in any society is an abnormal behavior. If these abnormal acts are pronouncedly deviant and pose threat to communal peace and order, then they are known as crimes. Therefore, crime may be defined as an act inimical to social peace and harmony. So, crimes are hurtful to social stability, and are more expected to appear in larger cities. To be able to control and prevent crimes, we need to study the various causes and roots of crimes in a systematic manner. However, the discipline involved in such a systematic investigation is known as criminology.

One of the increasing vulnerabilities observed in megacities at present is addiction in general within the young cohorts which often leads to prostitution by the female youth. When any female allows use of her body for sexual relation against payment of some money to many persons, this is an immoral activity and poses a threat to the society. Prostitution is considered immoral and unsocial because it commercializes and degenerates love, and asserts the supremacy of bodily values over social and moral. 


\section{Scope of Criminology}

The scope of criminology is quite vast and wide. It is relates to all social classes and structures. However, criminologists have tried to limit its scope so as to be able to study the subject scientifically and systematically. To elaborate it, here are the viewpoints of some notable criminologists: According to the science of criminology "includes within its scope the process of making laws, of breaking laws, and of reacting towards the breaking of laws" [1]. According to Sutherland's description of the scope of criminology, we can divide it into departments: The sociology of law, criminal etiology and penology. However, social psychologists have also maintained their applied interests with contributions in the social psychology of health, education, law and workplace [2].

\section{The viewpoints of Elliot and Merrill (1961)}

The eminent scholars Elliot and Merrill have made exhaustive and thorough study regarding the scope of criminology as follows: Nature of crime, investigation into causes of crime, individualized study of criminals and finally study of prevention of crime and reform of the criminal. Since offences committed by criminals are crimes; and as crimes occur in society, the term criminology fully means a study of crimes as well as criminals in relation to society with special reference to larger cities. How do social laws, conventions and traditions get formulated? How and why does an individual break them? Is there an element of compulsion or coercion in his/her defiance of the law? Or it is deliberate? These and other allied matters are studied by criminology with a view to find adequate answers which may help in formulating the effective preventive measures and controls in large urban areas. Similarly, the reaction of society towards a criminal, and this disposition of criminal towards a given society are the important matters for investigation which would help to adequately understand the phenomenon of crime.

\section{Urban Growth and the Trend of Crimes}

From the viewpoint of urban pathology, it is always expected to have more crime in cities. As the pattern of urban areas are always subject to change, and the citizens cannot easily conform to the new lifestyles, they are prone to deviations of all kinds_manifest and latent. While the deviants and criminals were of older age groups, they are nowadays of age groups 20 or younger, and that includes more individuals. This change of trend is counted for as a big threat to society as a whole.

Generally speaking, all types of crimes are on increase, and the increase is not just related to the USA [3]. Statistics show that in Britain and Wales in 1900, there was 3 crimes for every 1000 people, while in 1974 it had increased by 13 times to; 40 crime for every 1000 people. Such an increase could be observed in every society. That is due to increasing urbanization, change in traditions, cultural change, emergence of new different classes of people etc. The trends that industrial societies experienced at the outset of the 20th century, developing societies have experienced in the last decades of the 20th century. Therefore, social pathologists and social psychologists need to intervene and play better roles to pacify the situation. Crimes and delinquencies if not controlled in a society, they will be unpreventable after sometime [4]. For example, if supposedly there are two germs at the bottom of a bucket of water, statistically, they will double every hour, and then the bucket will be full of germs, after one hundred hours. Thus, deviance and crimes are prone to increase in the same way in a society. The extension of rural poverty while transferred to urban areas through migration, it contributes to the emergence of crimes [5].

As investigated, delinquencies of the adolescents also in different types and forms being on increase, have moved from the US to Europe [6]. Such a phenomenon has abnormally entered large cities of the world, and widely affected the youth as the most vulnerable people. Emile Durkheim stated that the phenomenon of crime has a world-wide nature. While it is the break-down of law, it threats the welfare and the normal conditions of the people of any society, and it usually occurs in urban societies. Regardless of socio-economic conditions of societies, crimes develop in all societies [7]. Its development is more due to the development of communications within societies.

\section{Method of Research}

The problem of research being socially useful and researchable made the researcher formulate the frame work. The work involves identification and selection of research problem (conceptual model). While using qualitative method of research, the researcher referred to some relevant resources to collect the necessary data on criminology, rate of crimes and the population density in mega-cities. The presented work in brief would reflect an image of the problem. Social pathology much helps to control the crimes with special reference to lager cities where people of different cultures gather to work and live.

\section{Table 1}

\section{Increasing Trend of Crimes in US 1968-1980}

\begin{tabular}{|l|l|}
\hline Year & Rate of Crime within Every 1000 People \\
\hline 1968 & 34 \\
\hline 1969 & 37 \\
\hline 1970 & 40 \\
\hline 1971 & 42 \\
\hline 1972 & 40 \\
\hline 1973 & 42 \\
\hline 1974 & 49 \\
\hline 1975 & 53 \\
\hline 1976 & 53 \\
\hline 1977 & 51 \\
\hline 1378 & 51 \\
\hline 1979 & 55 \\
\hline 1980 & 59 \\
\hline
\end{tabular}

Source: DisasterCenter.com 
The above table represents the increasing trend of crimes in an extra-ordinary industrial and urban society with all watch and controls. The frequency of crimes almost doubled within 22 years. Other countries are also so, or even worse in developing countries such as Iran with increasing economic imbalance.

\section{Multiple Causation of Prostitution}

The social researches made so far into the causes of prostitution reveal that females irrespective of age are drawn into it for a variety of reasons including poverty in general. That depends on various societies. There are also many who have adopted it after a series of love exploits. Though economic factor is quite important, it is liable to be overemphasized. The citing of hunger and poverty as reasons for prostitution seems to absolve the prostitute of all blames, and the sympathy of society.

Since increasing number of the youth including the females are afflicted with narcotics, in modern times, many of the addicted females forcefully are drawn to prostitution illegally and underground to secure their drugs. Such kind of drug hunger and drug need change their whole life and destiny. Such interactions are easily observed in large cities. Women who are addicts assume an enormous amount of risk (http://rehabinternational.org/drug-addiction/dangres/) that is physical as well as social. One of those risks is the increased threat of sexual attack or assault while under the influence, or simply due to being around the wrong kind of people at the wrong time.

One increasing common issue across the industrial societies is the rate of young women from the suburbs who get involved in prostitution rings or sex trafficking. Why is this so happening? Increased rates of drug abuse in the suburbs has led to increased rates of other drug-related issues like sex work and similar crimes. Too often, addicts ignore the signs of danger when they have the option to get high, and the end result can be deadly (http://rehab-international.org/drug-addiction/signs/).

The chief causes of prostitution can be classified in the following categories:

1. Economic causes

2. Social causes

3. Psychological causes

4. Biological causes

5. Religious and cultural causes

1. Economic causes - Though the economic compulsions constitute the major factor in the causation of prostitution, it is by no means the only and exclusive cause of the phenomenon. There are many prostitutes who hail from well-to-do families.

2. The social causes - The social causes are extremely important factors in encouraging and promoting prostitution. The social factors are comprised of family causes, marital causes, bad neighborhood and illegitimate motherhood.
3. Psychological causes - There are some psychological facts which tend the person towards prostitution. A woman who is frigid, becomes desperate. She tries one man after another. Because of frigidity, she is unable to experience pleasure, and becomes a prostitute by trial and error. Some women are incapable of submission. In order to assert their independence, they consort with other men.

4. Biological factors - The persons born with defective sex organs or overactive glands, may feel compelled to seek sex gratification in a bizarre manner.

5. Religion and cultural factors - This type of prostitution is much in relevance with temple institution wherein a woman is required to perform an initial act of prostitution before she could marry [8]. In this category of deviance, a woman is dedicated to the service of the temple either for a specific term, or more commonly for life. To better clarify the concept, in South India formerly, every family was supposed to offer one daughter to the temple where apparently she was supposed to serve gods with total dedication. They were known as Devadasis, or god-salves. But, in actual practice they lived a life of prostitution.

\section{Social Network and Social Deviation}

Social media increasingly affect social behavior in various ways including prostitution of all types; whether hidden or open in all societies. Such media highly affect the youth; especially those who are addicts. According to Ronald Weitzer, Professor of Sociology of the George Washington University (http:// sociology. columbian. gwu. edu/ronald-weitzer), there are no clear answers to estimate the exact correlation between hiring prostitutes and social media sites, although asking questions can bring us closer to reality. In modern times, because of easy contacts through the social networks, many females are lured to get into prostitution, drug addiction and other such deviant behaviors followed by more vulnerabilities in every part of the world. This type of behavior has effectively impacted family network, legal births and the normal family appearance.

\section{Social Pathology}

To study social problems, sociologists need to diagnose the roots of such problems, and for that, they have to use social pathology_a search for social and psychological causes in the mind of the criminal. It was Durkheim (1858-1917) when was alone able to see crime as normal, and appreciate that yesterday's "pathology" is today's normality. The term is now obsolete, and the last serious use being by E.M.Lemert [8].

In pathology we study abnormalities and diseases of the body of society. In the same way the sociologists study the structure of society and its substructures, and after that study the functional aspects of the society. When we study the abnormal functions of social relations, crimes and deviations of normal social relations, this branch of study is christened social pathology.

The social structure, unlike bodily structure, is not concrete and is abstract. The various structures other than social show a definite relationship between its substructures and these relations are not only definite, but are also relatively fixed and 
stable. But the relationship between social structure and its substructures is neither fixed nor definite. It is dynamic and fluid. Therefore, society is a dynamic organization in which changes are constantly occurring, and because of that crimes are likely to emerge.

In order to clearly understand the nature of social pathology, it is advisable to quote definition by John Lewis Gillin and John Philip Gillin. "By social pathology we mean such serious maladjustments between the various elements in the cultural configuration so as to endanger the survival of the group, or as seriously to interfere into the satisfactions of the fundamental desire of its members, with the result that social cohesion is destroyed".

John Lewis Gillin in his work had defined social pathology thus: "Social pathology is the study of man's failure to adjust him/ herself and his/her institutions to the necessities of existence to the end that he/she may survive and meet fairly with the felt needs of his/her nature"[9]. In short, the meaning and import of social pathology is that, it studies the social structure and substructures as institutions, groups and cultural elements with special reference to the exhibition of disintegration and imbalance. However, the intent and purpose of social pathology is to determine the factors which lead to imbalance, maladjustment and consequently disintegration with special reference to the densely- urban areas. If we know what ails a group, and what the factors which generate tension and conflict are, we can restore readjustment by adopting remedial measures. Accordingly, social pathology is a diagnostic science like medical pathology; both try to determine the causes, general and specific, of the disease. Therefore, social pathology includes under it purview all problems related to maladjustment and social disorganization. It very much helps in the study of sociology of crimes and criminology.

\section{Functional Theory of Crimes}

Based on this theory, the emergence of crimes is much related to the society; therefore it is not an imported phenomenon, but a derivative of society. In other words, the emergence of crimes originates from the social structure of a society. In case the urban administration does not continue in an intersectoral manner, the frequency of crimes will rise. Merton as an American sociologists adds: in case people do not reach their goals and aspirations, settings are made ready for any deviations and crimes to achieve the desired goals [10].

However, societies need to gather and analyze data on vulnerable individuals and populations in order to construct healthy societies and more sustainable social health. They must also properly target adequate social policies [11]. In urban areas, in some cases it is necessary to incapacitate the criminal from the scene in order to control the violence. In this way, the urban security would be in less danger [12].

\section{Conclusion}

As found out, increasing types of deviations is inevitable in densely-population areas with special reference to the developing world. Various thinkers such as Sutherland, Elliot etc. are of the opinion that criminology must be used in order to measure crimes, their roots, and eventually prevent them from further spreading. Increasing urbanization, and the changing societies make the grounds suitable for the emergence of vulnerable citizens, or what we call criminals in this paper. However, social pathologists and social psychologists could be accompanied by the criminologists to intervene to reduce crimes especially in larger cities. Similarly, breaking law and committing crimes, is a threat to the welfare and the normal conditions of the people of any society.

Drug addiction generally leads to personal disorganization. Such a habit generates serious problems including prostitution with special reference to the poor and the underclass all over the world. However, addictive habit affects the women morally, socially and economically. The excessive addiction robs human being of his/her sense of discrimination, he/she is unable to distinguish between good and bad, right and wrong, and that is where prostitution begins. Thus, drug use produces personality disintegration, and is a chief cause of family disorganization. The drug use also affects the life of children in a negative way.

\section{References:}

1. Sutherland EH Donald R Cressey, David F Luckenbell (1992) Principles of Criminology, 11th ed., Alta Mira Press.

2. Saul M Kassin, Steven Fein, Hazel Rose Markus, Sharon S Brehm (2017) Social Psychology (10 edition), Belmont, CA: Cengage Learning.

3. Radzinowicz, Sir Leon, J King (1977) The Growth of Crime: The International Experience, New York: Basic.

4. Price DO (1967) The 99th Hour, Chapell Hill: University of North Carolina Press.

5. Research Digest(2007) World Bank, Volume 1: 4.

6. Shipler DK (1978) Soviet Crime Problem Tied to City Life and Social Ills, The New York Times.

7. Durkheim E (1964) The Division of Labor in Society, George Simpson (trans), New York: Free Press.

8. Gillin, J.L., and J.P. Gillin, (2006). An Introduction to Sociology, Michigan: Macmillan

9. Merton R (1968) Social Theory and Social Structure, Enlarged ed. New York Free Press.

10. Lemert E M (1951) Social Pathology, New York: McGrawHill.

11. Oris M, Roberts C, Joye D, Ernst Stähli M (2016) Surveying Human Vulnerabilities across the Life Course, Dortrecht: Springer. 
12. Shinnar R, S Shinaar (1975)"The Effects of the Criminal Justice System on the Control of Crime: A Qualitative Approach", Law and Society Review 9: 581-611.

13. Durkheim, Emile (1958-1917) Internet Encyclopedia of Philosophy.

14. Elliot MA, FE Merrill (1961) Social Disorganization, Harper.

15. http://rehab-international.org/drug-addiction/dangres/

16. http://rehab-international.org/drug-addiction/signs/

17. http://sociology. columbian. gwu. edu/ronald-weitzer

18. Henslin JM, Light DW (1983) Social Problems, New York: McGraw-Hill.

Copyright: (C2020 Mohammad Taghi Sheykhi This is an open-access article distributed under the terms of the Creative Commons Attribution License, which permits unrestricted use, distribution, and reproduction in any medium, provided the original author and source are credited. 